\title{
How institutions matter for job characteristics, quality and experiences: A comparison of home care work for older people in Australia and Sweden
}

Gabrielle Meagher, Macquarie University and Stockholm University

Marta Szebehely, Stockholm University

Jane Mears, Western Sydney University

Accepted for publication in Work, Employment \& Society, November 2015,

First published OnlineFirst on February 29, 2016 as doi:10.1177/0950017015625601

http://wes.sagepub.com/content/early/2016/02/16/0950017015625601.full.pdf+html

\begin{abstract}
This article seeks to understand a puzzling finding: that workers in publiclyfunded home care for older people in Australia, compared to those in Sweden, feel that they are better able to meet their clients' needs, that their workplaces are less pressed, and that their work is less burdensome and more compatible with their family and social commitments. This finding seems to challenge expectations fostered by comparative sociological research that job quality and care services are inferior in Australia compared to Sweden. Informed by comparative institutionalist theory and care research, the structures and dynamics of the care systems in the two countries are analyzed, along with findings from the NORDCARE survey of home care workers conducted in Sweden in $2005(n=166)$ and Australia in $2010(n=318)$. Differences in the work and working conditions in the two countries are explained by the dynamic interaction of national institutional and highly gendered sector-level effects.
\end{abstract}

Keywords: Australia, comparative institutionalism, gender, home care work, job quality, Sweden 


\section{Introduction}

This article seeks to understand a puzzling finding: why workers in publicly-funded, formal home care for older people in Australia, compared to those in Sweden, feel that they are better able to meet their clients' needs, that their workplaces are less pressed, and that their work is less burdensome and more compatible with their family and social commitments. The finding, which emerged in the comparative analysis reported here, is puzzling because it seems to challenge expectations fostered by research in comparative sociology that both the quality of jobs (Dobbin \& Boychuk 1999) and the coverage of welfare services is lower in Australia than in Sweden (Esping-Andersen 1990).

This article extends the empirical range of comparative, sector-specific research on work to the social services, with a mixed-method study of work in publicly-funded, home care services for older people in Australia and Sweden. It joins feminist research on care work with institutionalist theorizing about diversity of capitalism, thereby contributing to 'gendering perspectives in cross-national comparative research on work and welfare' (O'Reilly, 2006). Home care for older people is a particularly interesting case for crossnational comparison, because it is both a form of work and a welfare service, and so is directly shaped by the institutions of employment and of welfare. It is intimately connected with questions of gender in both sets of institutions, in the employment sphere as a poorly paid, highly feminised job (Atkinson and Lucas, 2013; Rubery and Urwin, 2011), and in the welfare sphere as a partial substitute for unpaid family care typically undertaken by women (Anxo and Fagan, 2005). We show how significant differences in the content, work organization and employment conditions in Australia and Sweden are shaped by their distinct national institutional arrangements, and also by sector-specific factors related to the gendered nature of social services work.

\section{Comparing job characteristics and quality: strategies and frameworks}

One important strategy for theory-testing and refinement in recent cross-national comparative sociology of work is to study specific job characteristics, such as job autonomy (Dobbin and Boychuk, 1999; Gallie, 2007; Holman, 2013) and/or specific occupations (Askenazy et al., 2012; Bosch and Lehndorff, 2005). Methods vary within this body of work, from quantitative theory testing and measure development (Holman, 2013), to qualitative case studies drawing on interviews, observation, secondary data and document analysis (Askenazy et al., 2012, Lloyd and Payne, 2013). A particular value of comparative studies of single occupations is that their multi-method or qualitative research strategies allow more fine-grained analysis of tasks and job organization. Thus, researchers can 'look inside' job classifications that, as Gallie (2007:90) suggests, might mistakenly be assumed to capture the same job content in different countries. By narrowing the focus to a single job, such studies can consider sectorspecific factors that may shape the job in question similarly in different national contexts alongside country-specific institutional arrangements. 
Like the present study, these studies of specific occupations are framed in dialogue with institutionalist research, which seeks to theorize patterned differences in economic and social organization observed between nations and clusters of nations. This research develops several 'typologies of capitalist diversity' (Schröder, 2013), such as 'production regimes' (Gallie, 2007), 'national employment systems' (Dobbin and Boychuk, 1999), 'varieties of capitalism' (Hall and Soskice, 2001) and 'welfare regimes' (Esping-Andersen, 1990), which categorize societies according to the institutional arrangements and structured conflicts that organize them. The extent to which the regimes or systems are converging under various pressures, or remain distinct, is a key debate in this field (Gallie, 2007; Schröder, 2013).

Significantly, many studies of particular jobs focus on the service sector, including consumer service occupations such as fitness instructors (Lloyd and Payne, 2013) and cashiers in large food retailers (Askenazy et al., 2012), or business service work in call centres (Holman, 2013). Analysts of service sector jobs aim to test or extend comparative theoretical frames 'developed from research on a narrow range of manufacturing industries' (Lloyd and Payne, 2013:4). The increasing proportion of total employment in services is one driver of this interest, but so too is an interest in women's employment, and in how the institutions of work and welfare, along with broader social and demographic forces, shape female labour supply (Askenazy et al., 2012; Bosch and Lehndorff, 2005). The present study's focus on home care work extends the field further, by contributing a close study of a highly gendered social service job.

Comparative institutional theories can be used to identify the institutions and processes (regimes or systems) that shape a specific job in different countries, therefore researchers who study specific jobs use these theories to guide and structure their case analysis (e.g. Askenazy et al., 2012). In the present study an important starting point is how models of capitalist diversity have categorized Australia and Sweden, and explained their respective institutional arrangements. Comparative models of economic and employment systems categorize Australia as a liberal market economy (along with the UK, the US, Canada), and Sweden as co-ordinated market economy (along with the other Nordic countries). Other models that focus on work and welfare arrangements generally categorize Australia as a liberal welfare regime and Sweden as a social democratic welfare regime (Esping-Andersen 1990). Working with these models, researchers consistently find job quality to be higher, on average, in Nordic than in English-speaking countries (e.g. Dobbin and Boychuk, 1999; Gallie, 2007; Holman, 2013). Social security is also found to be higher, and inequality lower, in the universalistic social democratic than in liberal welfare regimes (Esping-Andersen, 1990; Kammer et al., 2012). The two sets of findings are connected: higher job quality is enabled by institutions of co-determination, strong vocational training, security of employment and extensive welfare supports that tend to decommodify labour in the Nordic countries, while the freer play of market forces, the more rule-bound character of industrial relations and the greater power of employers in liberal countries impede the development of welfare supports, reduce union power, depress job quality, increase worker and citizen insecurity and engender higher inequality (Gallie, 2007). 
We broadly accept — and build on - these arguments and findings. However, as O'Reilly (2006:745) argues 'looking for lack of fit and contradictions' is a generative strategy when engaging with models in comparative research, particularly when these models have historically been developed by reference to male norms.

\section{Home care: care work and care services under pressure}

Home care for older people is a form of care work, which feminist research shows has specific characteristics that distinguish it from work in the service sector generally (Himmelweit, 1999). Care work has important relational as well as practical dimensions and the quality of paid care services depends on workers' capacity to develop caring relationships with the people they help (Himmelweit, 1999; Wærness, 1984). Further, good caring relationships are enabled by dimensions of job quality. These include work organization, such as sufficient time in the care encounter to manage practical and relational work, and sufficient skills and autonomy to respond to (changing) individual needs (Fisher and Tronto, 1990; Stone, 2000). Employment conditions are also important: adequate pay, non-precarious employment, a reasonable distribution of shifts and hours of work, and enough hours of work are needed to retain care workers so to give caring relationships time to develop and for continuity of care (Rubery and Urwin, 2011).

Home care is also a welfare service, organized within a country's social care system. Thus, home care is shaped by the institutions of the welfare state, and the goals, structure, level of development and trajectory of change of care systems vary across regimes (Anttonen and Sipilä, 1996). Care for older people is also a 'sector' for present analytical purposes, subject to common pressures and trends. Care systems are changing in most rich countries, as they confront population ageing and pressure to contain costs. These changes are affecting the profile of service users and the content and organisation of services. Common trends include a shift from residential to home care, tightening budgets and growing reliance on market mechanisms to co-ordinate care systems (Anxo and Fagan, 2005; Ranci and Pavolini, 2013; Rostgaard et al., 2012).

The characteristics, organization and experience of home care work have been researched in many countries. Consistent findings are that home care is a female-dominated occupation with low status and relatively poor pay. Institutional recognition of the skills of home care workers is weak, reflecting the pervasive, gendered undervaluation of care work (Atkinson and Lucas, 2013). Workers find the opportunity to help older people rewarding, but find that they often need to work against or around the demands of employing organizations to offer the kind of care they believe meets the needs of care recipients (Dahl, 2009; Stone, 2000).

Several single-country studies examine the impact of policy changes on work and employment conditions for home care workers. In these studies, policy change involves marketization in some form, often related to the emergence of New Public Management (NPM), which proponents argued would make public services more efficient and effective through the use of practices drawn from the private sector (Christiansen and Lægreid, 2002). Researchers have analyzed the introduction of managed markets in Ontario (Aronson and 
Neysmith, 2006; Denton et al., 2002) and in England (Rubery and Urwin, 2011), privatization in Japan (Broadbent, 2013), and NPM in the Netherlands (Knijn, 2000), England (Atkinson and Lucas, 2013), Denmark (Dahl, 2009), Norway (Vabø, 2006), and Sweden (Szebehely and Trydegård, 2012). These studies find that NPM involved time-and-task work re-organization or 'taylorization' of home care work, which workers reported made it more difficult to provide high quality care.

Research on home care in Australia paints a somewhat more positive picture. Two large quantitative studies found that overall worker satisfaction was high, and remained stable between 2007 and 2012. Workers reported having time to care and relatively low pressure and stress. However, employment conditions were poor: a large proportion of workers had insecure employment and were unsatisfied with their pay (King et al., 2013a; King et al., 2013b).

There are a handful of multi-country and/or comparative studies of home care work. These include studies of Nordic home care based on the NORDCARE survey used in the present study (e.g. Elstad and Vabø, 2008; Trydegård, 2012), and which was conducted in Sweden, Denmark, Norway and Finland in 2005 and later in Canada (2006), Iceland (2009), Germany (2010), Australia (2010) and Japan (2019). A single, comparative study by Stranz (2013) analyses the relationship between home care workers' employment and working conditions and institutional arrangements in Sweden and Denmark. Stranz found many similarities between the two countries, which is not surprising, as both are social democratic welfare regimes. However, Danish home care workers were more likely to say that their working conditions and capacity to assist care recipients had worsened in recent years, reflecting the more recent introduction of taylorized work organization there, compared to Sweden, where it was well-established by the time of the survey.

Taken together, studies of home care suggest that a complex mix of national institutional arrangements and sectoral trends shapes the organization of this work and the quality of jobs in it. Gendered institutional structures of work and welfare lead to the undervaluation of home care work and hold back improvement of working conditions, while New Public Management has reduced the quality of jobs and services in home care in many countries.

\section{Institutional arrangements and dynamics}

\section{Two home care systems: institutional structures}

Structural differences between the systems of care for older people in Australia and Sweden reflect their embeddedness in liberal and social democratic welfare regimes, respectively. The formal care system is larger in Sweden than in Australia, and this difference can only partly be explained by the larger share of older people in Sweden's population. As Table 1 shows, public expenditure on care services in Sweden is three times higher, and Sweden's long-term care workforce relative to the size of the population over 80 years is more than twice the size 
of Australia's. This pattern can be explained by the relationship between welfare regimes and gendered patterns of employment: social democratic welfare states have both high levels of public service delivery and high female participation in paid work, reflecting the high ambitions of their welfare service systems (Anttonen and Sipilä, 1996). Hence, a higher proportion of Swedish than Australian women participate in paid work and are employed at least 30 hours a week. In Australia, responsibility for care for older people is left more to the family (family care in this context refers to unpaid care provided by family and kin). Family carers' labour force participation is therefore more affected in Australia than in Sweden (Kröger and Yeandle, 2013). As Table 1 shows considerably more Australian family carers provide intensive care.

\section{TABLE 1 HERE}

\section{Trends in spending and service coverage}

Comparison of developments over time reveals a somewhat different picture. In Sweden, public spending on care services per older person increased in the 1980s. However, since 1990, expenditure has been declining, relative to the proportion of older people in the population, by an annual average of 0.5 per cent between 1990 and 2000, by 1.4 per cent between 2000 and 2005 and by 0.3 per cent between 2005 and 2012 (SALAR, 2014:20). In Australia, by contrast, real public expenditure per older person on care services has been increasing. Average annual spending grew by 3.7 per cent between 1991 and 2000, and by 2.4 per cent between 2000 and 2011 (authors' calculations based on official sources; see Supplementary file).

These spending trends have affected coverage in both countries. Figure 1 shows the coverage of publicly-subsidized help provided to older people in their homes following needs assessment (home care) and of long-term care in a residential setting where 24-hour care is offered (residential care). In Sweden, 16 per cent of the older population (65+) received home care in 1980. Coverage declined during the 1980s and 1990s, to 9 per cent by 2012. The coverage of residential care has also declined, from the late1990s. At that time, 8 per cent of older people lived in residential care, compared to 5 per cent in 2012. In Australia, by contrast, coverage has been on a (slow) growth path overall. Coverage of home care has increased, following the establishment of several programs since the mid-1980s. In 2003, nearly 11 per cent of people aged 65+ received home care, rising to 13 per cent in 2012 (see Figure 1; data for earlier years not available). Residential care coverage has fallen slightly in recent decades, following rapid growth from the 1960s to the 1980s (Healy, 2002), and was just above 5 per cent of the population aged 65+ in 2012 .

It seems perplexing that coverage is now higher in Australia than in Sweden: although spending has not kept pace with the ageing population in Sweden, it remains considerably higher than in Australia. To resolve this contradiction, we compared the intensity of home care services in each country (intensity measured as number of hours provided) and charted 
the distribution of users receiving services of different intensity (Figure 1; see Supplementary file for methods and sources). This analysis showed that the vast majority of Australian home care users in 2012 received low intensity help, although medium and high intensity services expanded over the last decade. By contrast, in Sweden, home care services are more evenly spread between low, medium and high intensity, and the average hours for high intensity help are much higher (23.6) than in Australia (14.5). This explains the differences in system structure evident in Table 1, notably the higher spending on, and higher employment in, Swedish care for older people.

\section{FIGURE 1 HERE}

\section{Service organization and the differential impact of New Public Management}

Important differences between Sweden and Australia also arise from the organization of home care and its relationship to the scale and ambition of the service system. In Sweden, home care was developed as a public service with universalist ambitions in the 1950s and 1960s. However, with an increased focus on cost containment during the 1980s, services became more targeted as well as predefined, standardized and fragmented. This considerably reduced the discretionary power of care workers (Eliasson Lappalainen and Motevasel, 1997). In the 1990s, the tendency to reframe publicly-funded home care as a 'product' was reinforced by the impact of NPM. Many local authorities introduced a 'purchaser-provider split', thereby increasing the distance between the assessment of needs and the provision of help. This change required increased precision in needs assessment, which in turn connected work tasks to a standardized time frame ( 5 minutes to make a bed, 10 minutes to change incontinence pads). Combined with the increased client needs, service fragmentation also increased the number of visits per day made by care workers. New instruments were developed for measuring the quality of care and for ensuring that the tasks performed accord with the needs assessment (Vabø and Szebehely, 2012). These developments have occurred without any change in the framing legislation that established the system's universalistic ambitions. If anything, these ambitions have increased, while resources have not. Local authorities remain responsible for financing, assessing and meeting the needs of the older people within their municipalities, including when services are outsourced to private providers - a trend that started in the early 1990s (Brennan et al., 2012).

In Australia, the level of ambition and the degree of integration of the system of care for older people have, until recent decades, been low. Further, rationalizing pressures, although present, are weaker than in Sweden. The Australian system is a fragmented mixed economy organized over much larger areas, and needs assessment and service allocation are not centrally coordinated. Thus, unlike Swedish local authorities, although publicly funded, most provider organizations have no binding responsibility to meet the needs of all in a specific community. Consequently, although despite significant unmet need (Productivity Commission, 2013), there has been no structural mechanism to transmit the corresponding pressure to individual service providing organizations. Rather, the mostly non-profit providers are responsible only to serve well the clients they have, within the scope of funding received. Public providers are 
a partial exception, because they typically act as provider of last resort for difficult clients and are often the sole service providers in remote regions (Davidson, 2015).

Despite increasing funds, there are some rationalizing pressures on the everyday operation of Australian home care services (Mears, 2006). However, these pressures have not been as urgent at the organizational/workplace level in Australia as they have been in Sweden. Importantly, there is little evidence that Australian home care work has been taylorized. From the 1990s, NPM affected how funding was distributed (e.g. via competitive tendering for new funds), but by that time non-profit providers were long established and highly trusted (Davidson, 2015). In general, providers have been left to find their own ways of organizing home care work, without highly detailed steering. This leaves room for care managers to arrange care services in ways that sustain care relationships.

Thus, institutional arrangements in the two countries, especially the level of ambition and of development of their care systems, foster the expectation that workers in the better-resourced and more ambitious Swedish system would be better off. However, dynamic factors complicate the picture. In Sweden, rationalizing pressures have operated in ways that would be expected to worsen conditions for workers. Meanwhile, in Australia, although the formal care system has historically been underdeveloped, in recent decades both ambitions and resources have grown, which might be expected to improve care workers' situation.

\section{Working in home care in Australia and Sweden}

To explore how institutional structures and trends are shaping the content of home care work and the quality of home care jobs in Australia and Sweden the two countries, this section presents analysis of data from the NORDCARE project, supplemented by other official and research sources. The NORDCARE survey, developed by the research team, asked care workers about the content of their working day, their employment and working conditions and their evaluations of various aspects of their work situation.

In 2005, a mail survey was sent to a random sample of 1,200 unionized care workers in homeand residential care for older and disabled people in each of Sweden, Denmark, Norway and Finland. At that time, around 80 per cent of care workers in Sweden were unionized. Workers in services for older and disabled people, in both home-based and residential care, were included, and the response rate was 67 per cent $(\mathrm{N}=735$, of which $\mathrm{n}=212$ worked in home care of older people). As reported above, the instrument was subsequently translated and distributed to care workers in other countries, including Australia. There, different sampling and distribution methods were required because of the dispersion of providers in the mixed economy and low union density. A stratified, systematic cluster sample ${ }^{1}$ of all organizations receiving public funding to provide home care in New South Wales was taken, and 1,093 questionnaires were distributed in workplaces of the selected organizations in 2010. The response rate was 49 per cent $(\mathrm{N}=537$, of which $\mathrm{n}=515$ worked in home care of older people). Although administered in one state of Australia only, we are confident the findings can be generalized to Australia as a whole. This is because employment conditions are relatively uniform across the national care workforce, shaped by the dominant role of federal 
institutions in making policy and in funding care services and in industrial relations (King et al., 2013b). Further, the gap in time between the surveys in the two countries was not considered a limitation, because the results in each country have been interpreted against their respective institutional contexts, not a common external reference point. Thus, simultaneous data collection was not required to make valid findings. All analyses presented are based on the subsample who have responded to all items reported in Tables 2-5 (Australia: $n=318$; Sweden: $n=166$ ).

Analysis was undertaken using SPSS version 20. Cross-tabulation with chi-squared tests was used to present a broad descriptive comparison of Sweden and Australia, followed by a series of multivariate logistic regressions that enabled comparison of workers' evaluations of their work situation, controlling for differences in job content, worker tenure and other factors likely to affect workers' evaluations.

\section{Care workers: characteristics and employment conditions}

We begin by comparing the characteristics of the care workers and their employment conditions in the two countries (Table 2). The main, and unsurprising, similarity between them was that home care was strongly female-dominated in both. However, there were some important differences, which conform to the general findings of comparative institutional theory. Swedish home care workers were, on average, younger than those in the Australian group, but had been employed significantly longer in home care. ${ }^{2}$ Further, basic employment conditions in home care were better in Sweden than in Australia. Swedish workers were significantly more likely to work full-time (four in ten compared to one in seven in Australia), to have lower rates of short-part-time hours and insecure employment, and to be satisfied with their working hours. These findings were corroborated by other data. The rate of pay of Swedish home care workers was equivalent to 79 per cent of the national average (Statistics Sweden, 2013), while the corresponding figure for Australia was 60 per cent (ABS, 2011a). In both countries, forms of collective agreement largely determined these rates.

\section{TABLE 2 HERE}

While employment conditions, working hours and relative pay were better in Sweden than in Australia, Table 3 shows that other working conditions related to work scheduling and worklife balance were less favourable in Sweden. Swedish care workers were much more likely to work unsociable hours at weekends, evenings and nights than those in Australia (Panel A). Focussing on individual workers' schedules provides a clearer picture (Panel B). Among Swedish workers, only 17 per cent worked one shift only - of these, half worked weekdays, daytime only and half worked nights only. By contrast, among Australian workers, close to two-thirds worked one shift only and the vast majority of these worked daytime, weekday shifts only. Thus, more than 90 per cent of the Swedish workers worked unsociable hours compared to one third of the Australian workers. Work-life balance diverged accordingly: Swedish workers were significantly less likely to say their working hours fitted 'very well' with their family and social commitments (16 per cent versus 52 per cent in Australia; Panel C). 


\section{TABLE 3 HERE}

There were some important differences between working conditions for care workers in Australia and Sweden, but some key employment conditions are worse than national averages in both countries. In Sweden, part-time work is much more common in home care than in other female-dominated jobs and for decades involuntary part-time work and comparatively insecure employment conditions in care work have been (and still are) an issue for the care workers' union (Kommunal, 2014). In Australia, the rate of part-time work in home care, at over 80 per cent, is much higher than the 43 per cent rate for women overall, while the rate of temporary employment is equivalent to the national average (ABS, 2011b). This confirms the findings of previous research on home care work, and suggests a sector-specific effect.

\section{Are home care tasks the same in Australia and Sweden?}

Home care typically consists of a mix of personal care ('body work'), household work and social support. The balance in the mix of tasks in the work of an individual reflects the skill demands of their job, while the mix in the home care system reflects the ambition of that system, and the needs profile of service users. One of the challenges in cross-national comparison of specific jobs is ensuring comparison of like with like. The NORDCARE questionnaire is particularly valuable here, since it contained detailed questions about type and frequency of home care tasks.

Table 4 shows that workers in both countries do carry out many similar tasks as part of their job. However, there are some significant differences in the task mix. Help with personal care was the most common task in both countries, but eight out of ten Swedish care workers lifted or assisted in moving a person daily, compared to one in three in Australia. This can be explained by the extent of service targeting on older people with highest needs in Sweden. Similarly, significantly more Swedish care workers reported doing medical tasks such as handing out medicine, giving an injection and participating in rehabilitation work. They were also much more likely to contact the health care system or other suppliers of care. In other words, the Swedish care workers did far more body work, which is physically demanding, but also more professionalized. Perhaps surprisingly, then, the level of training in the home care workforces is fairly similar in both countries. Formal training requirements are minimal, and about 25-30 percent of Swedish and Australian home care workers have no formal training (NBHW, 2013:149; King et al., 2013a:80). Further, career paths in home care work are severely limited, with pay progression minimal and extra training rewarded weakly, if at all, in both countries.

\section{TABLE 4 HERE}

While Swedish workers did more 'body work', Australian workers were more likely to report helping with both social aspects of care (such as having a cup of coffee or participating in a recreational activity) and with cleaning - the most physically demanding of household tasks. The difference between the two groups was even larger when measured as the proportion who reported cleaning a client's home several times a day - 51.9 per cent of the Australian 
workers compared to 9.0 per cent of the Swedish workers (not shown in the table). Regarding other household tasks, such as cooking a meal or shopping for groceries, there was no difference between the two countries.

Differences in the task mix partly reflect differences in the division of labour between the social care and health services in the two countries, evident in the fact that giving an injection is a somewhat common task for Swedish home care workers, but rare for the Australians. However, overall, the level of ambition of the care services system is more important. The higher intensity of home care in Sweden means that those with large care needs receive a comparatively large number of home care hours, including help with personal care.

Rationalization in recent decades has squeezed out the social support components of Swedish home care (Stranz, 2013; Vabø and Szebehely, 2012), which continue to be offered in Australia.

\section{Workers' assessments of job quality}

This section extends the analysis of job quality to other elements, including autonomy, which has been a strong focus in previous comparative research (Dobbin and Boychuk, 1999; Gallie 2007; Holman, 2013). Table 5 presents data on how workers assessed their workload, its physical and psychological impacts on them, the support they received from their immediate supervisor and their autonomy at work. The analytical strategy was to compare Australia and Sweden on these various dimensions of workload and job quality, with a final analysis controlling for differences in the workforce and task profiles in the two countries revealed in Tables 2 and 4 above. Panel A presents cross-tabulated frequencies with chi-squared tests; Panel B presents adjusted odds ratios based on multiple logistic regressions. The purpose of the multivariate analysis was to test whether differences between Sweden and Australia on each of these measures can be plausibly attributed to differences in institutional factors and system dynamics, by controlling for various individual and workload factors that may affect respondents' assessment of the demands of their work. Data were dichotomised for economy and clarity of presentation, for consistency with data previously reported, and to avoid problems with sparse data.

Note first that the vast majority of respondents in both countries reported that they got a lot out of working with their clients; confirming the findings of previous care research. Panel A shows that home care work was taxing in both countries, but a significantly higher proportion of Swedish workers reported that they had too much to do, and that their work was physically and psychologically burdensome. Feelings of not being able to provide enough care were also much more common among Swedish workers. Further, two measures suggest that the Swedish workers recognized the direction of change in Swedish home care; two-fifths reported that their working conditions had deteriorated and nearly half reported that their possibilities to meet clients' needs had deteriorated in recent years, compared to around one in eight Australian workers. On the two measures of autonomy, we found apparently contradictory results: as predicted by comparative institutional theory, Swedish workers were more likely to report that they could affect the planning of each day's work (34 per cent versus 22 per cent for Australians), but also more likely to agree that there was too much 
monitoring and control (37 per cent versus 20 per cent for Australians). Swedish workers also felt less supported by their immediate supervisor.

However, data presented in the previous sections showed that Swedish workers on average worked longer hours, had been employed in home care longer, and had more demanding tasks than the Australians, which may explain why Swedish workers felt more pressed and exhausted. Thus, multiple logistic regressions controlled for the content of work (all 12 tasks included in Table 4), hours worked and length of time in home care in years, along with age and gender (Panel B). Once these factors are controlled for, differences between workers in the two countries in physical and mental exhaustion and job autonomy and supervisory support were not significant. Nevertheless, Swedish workers remained at significantly higher risk of having too much to do at work, working in short-staffed workplaces, believing that their working conditions and capacity to meet client needs had deteriorated, and feeling inadequate about the care clients received.

\section{TABLE 5 HERE}

\section{Concluding discussion}

The findings of previous studies have been mixed in relation to confirming or challenging comparative institutional theory. For example, Lloyd and Payne (2013) found that sector effects overwhelmed national employment system (NES) effects in their study of fitness instructors in Norway and the UK, while Holman's (2013) eight-country study of call centre work confirmed the strength of NES over sector effects. Askenazy and colleagues (2012) posed an alternative resolution to NES versus sector effects, with their concept of 'nationalsectoral models'. They argue that national institutions of employment, but also those of product regulation and social reproduction more generally, interact with sector-specific imperatives in complex, iterative ways to differentiate jobs. Further, in addition to proposing the existence of 'national-sectoral models', Askenazy and colleagues conclude that the 'mutability in institutions, and thus societal effects, points to the need for further historical as well as comparative research' (2012:601).

The present study's most important contribution to comparative institutional theory is to take up this desideratum. By adding a dynamic, temporal-historical dimension to a structural analysis of national-sectoral models of home care in Sweden and Australia, we are able to explain otherwise puzzling divergences in workers' assessment of their jobs. Further, we argue that both objective trends in resources to the sector (falling in Sweden and rising in Australia) and subjective responses to these trends (and their relationship to national-political norms) are important for understanding our findings. Swedish workers work in a discursive context in which the state formally has full responsibility for caring for older people's needs, but does not live up to its promise. Australian workers work in a context where they are expected to support families in their caring responsibilities, without the promise of formal state responsibility. Thus, even though Australian workers do less, and in practice leave 
service users with larger unmet needs than Swedish workers, they do what policy rhetoric could lead them to expect of themselves and of the system, while Swedish workers find themselves unable to.

Yet at the same time, the present study has confirmed that typologies developed within comparative institutional sociology, and which take a structural or cross-sectional perspective, remain very valuable heuristics for understanding international difference. First, our findings confirm that national institutional structures matter for job quality in several key dimensions. The significantly higher prevalence in Australia of short working hours, involuntary part-time work, and very low relative pay is expected, given this country's liberal market institutional arrangements, while the better basic employment conditions and more extensive employment opportunities in Sweden are expected, given that country's social democratic institutional arrangements. National institutional structures also matter in home care when it comes to service provision, which is considerably less intensive in Australia than in Sweden - again, consistent with their liberal and social democratic welfare institutions, respectively.

The present study has also confirmed the value of looking inside job contents, as Gallie (2007) suggested and, related, of the impact of sector-specific effects. Home care is a somewhat different job in Australia and Sweden: its tasks and workload vary, as does its work organization. Despite these differences and the impact of national institutional structures, there is some evidence of convergence in home care service provision, under the common pressure of population ageing. In Australia, this has driven system expansion, while in Sweden it has driven rationalization, with clear effects on home care workers' evaluations of their situations, as discussed above. Further, as shown by Askenazy and colleagues, the interaction of national with sectoral effects matters too for job quality. In the home care sector, insights from care research about the gendered undervaluation of care services, skills and work are critically important. This helps explain why, despite expected differences between the countries, in both the quality of jobs in home care was lower than national averages in relation to pay and access to sufficient hours of work. Its sectoral focus means that care research also provides a framework for thinking about the relationship between job quality and service quality in the two countries. In Sweden, some employment conditions were more favourable to continuity and so to service quality, while working conditions and job organization, especially the impact of New Public Management, were less so. In Australia, employment conditions have undermined continuity, while work organization appeared to support workers' sense of their capacity to care.

This study has some limitations. The questionnaire did not include questions that enabled the full spectrum of job quality indicators to be assessed (e.g. such as those discussed in Rubery and Urwin, 2011). Further, policy on care services continues to evolve rapidly. In both countries, there have been significant changes since the surveys were conducted. In Sweden, the coverage of residential care has continued to decline, and conditions in home care have deteriorated further. Workers see more clients per day, and clients are visited by more workers. The share of for-profit providers has increased considerably, and these organisations 
offer less secure employment conditions. Family care has also increased, as relatives supplement pressed home care systems (NBHW, 2013b). In Australia, coverage has continued to rise, although the coverage of medium and high intensity services remains low. However, actual and planned organizational change, specifically, the introduction of consumer-directed care models, including a government commitment to allocate funding directly to service users (Morrison, 2015), may make employment less, rather than more, secure. Thus, it seems that improving the quality of home care jobs will remain challenging into the future in both countries.

\section{Funding information}

The research reported in this article was supported by the Swedish Research Council for Health, Working Life and Welfare (Grants nos. 2003-0462 and 2013-2296) and by the New South Wales Department of Disability Ageing and Home Care (2009).

\section{Notes}

${ }^{1}$ Sampling was undertaken in two stages. First, five (of sixteen) local planning areas (LPAs) in New South Wales, the most populous state in Australia, were selected to ensure representation of inner and outer urban, rural and remote areas. Funded organizations in these LPAs were stratified by provider type and a systematic sample drawn from each stratum. Altogether 20 private organizations and 15 geographical districts of the public provider were approached; all accepted the invitation to participate.

${ }^{2}$ In Australia, several of these measures can be compared with the only other Australian source, King et al.'s larger sample survey of aged care workers, which, however, had a much lower response rate (2013a). The two survey samples have similar gender and age compositions and minor differences in the proportions working full-time and non-permanent employment. In Sweden, the only notable difference between the sample and official sources is that temporary employment is lower in the sample (12 versus 21 per cent) (Stranz, 2013:77). This bias arises because the survey was distributed to union members, who are more likely to have secure employment.

\section{FUNDING}

The research reported in this article was supported by the Swedish Research Council for Health, Working Life and Welfare (grant nos. 2003-0462 and 2013-2296) and by the New South Wales Department of Disability Ageing and Home Care (2009). 


\section{REFERENCES}

ABS (2011a) Employee Earnings and Hours, May 2010. Canberra: Australian Bureau of Statistics.

ABS (2011b) Economic security: Employment conditions, Gender Indicators Australia, July 2011. Canberra: Australian Bureau of Statistics.

Anttonen A, Sipilä J (1996) European social care services: is it possible to identify models? Journal of European Social Policy 6(2), 87-100.

Anxo D and Fagan C (2005) The family, the state and the market: The organisation of employment and working time in home care services for the elderly. In: Bosch G and Lehndorff S (eds) Working in the Service Sector: A Tale from Different Worlds. Abingdon: Routledge, 133-164.

Aronson J, Neysmith S (2006) Obscuring the costs of home care: restructuring at work. Work, Employment and Society 20(1), 27-45.

Askenazy P, Berry J.-B, Carré F, Prunier-Poulmaire, S and Tilly C (2012) Working in large food retailers in France and the USA: the key role of institutions. Work, Employment \& Society 26(4), 588-605.

Atkinson C and Lucas R (2013) Policy and gender in adult social care. Public Administration 91(1), 159-173.

Bosch G and Lehndorff S (Eds.) (2005) Working in the Service Sector: A Tale from Different Worlds. Abingdon: Routledge.

Brennan D, Cass B, Himmelweit S and Szebehely M (2012) The marketisation of care: Rationales and consequences in Nordic and liberal care regimes. Journal of European Social Policy 22(4), 377-391.

Broadbent K (2013) 'I'd rather work in a supermarket': privatization of home care work in Japan. Work, Employment and Society, 28(5), 702-717.

Christensen T and Lægreid P (2002) New Public Management. The Transformations of Ideas and Practice. Hampshire: Ashgate.

Dahl HM (2009) New public management, care and struggles about recognition. Critical Social Policy 29(4), 634-654.

Davidson B (2015) Contestability in the Human Services and Its Impact on Service Providers: A Case Study of Community Aged Care in New South Wales. Unpublished doctoral thesis, University of NSW, Kensington.

Denton M, Zeytinoglu IU, Davies S and Lian J (2002) Job stress and job dissatisfaction of home care workers in the context of health care restructuring. International Journal of Health Services 32(2), 327-357.

Dobbin F and Boychuk T (1999) National employment systems and job autonomy: Why job autonomy is high in the Nordic countries and low in the United States, Canada, and Australia. Organization Studies 20(2), 257-291

Eliasson Lappalainen R, Motevasel I (1997) Ethics of care and social policy. Scandinavian Journal of Social Welfare 6(3), 189-196.

Elstad JI, Vabø M (2008) Job stress, sickness absence and sickness presenteeism in Nordic elderly care. Scandinavian Journal of Public Health 36(5), 467-474.

Esping-Andersen G (1990) The Three Worlds of Welfare Capitalism. Princeton: Princeton University Press. 
Fisher B, Tronto J (1990) Towards a feminist theory of caring. In: EK Abel, MK Nelson (eds) Circles of Care: Work and Identity in Women's Lives. Albany: SUNY Press, 35-62.

Gallie D (2007) Production regimes and the quality of employment in Europe. Annual Review of Sociology, 33, 85-104.

Hall PA and Soskice D (eds) (2001) Varieties of Capitalism. The Institutional Foundations of Comparative Advantage. Oxford: Oxford University Press.

Healy J (2002) The care of older people: Australia and the United Kingdom. Social Policy \& Administration 36(1), 1-19.

Himmelweit S (1999) Caring labor. Annals of the American Academy of Political and Social Science 561(1), 27-38.

Holman D (2013) An explanation of cross-national variation in call centre job quality using institutional theory. Work, Employment \& Society 27(1), 21-38.

Huber M, Rodrigues R, Hoffmann F, Gasior K and Marin B (2009) Facts and Figures on Long-Term Care - Europe and North America. Vienna: European Centre for Social Welfare Policy and Research.

Kammer A, Niehues J and Peichl A (2012) Welfare regimes and welfare state outcomes in Europe. Journal of European Social Policy 22(5), 455-471.

King D, Mavromaras K, Wei Z, et al. (2013a) The Aged Care Workforce, 2012. Canberra: Department of Health and Ageing.

King D, Wei Z and Howe A (2013b) Work satisfaction and intention to leave among direct care workers in community and residential aged care in Australia, Journal of Aging \& Social Policy 25(4), 301-319.

Knijn T (2000) Marketization and the struggling logics of (home) care in The Netherlands. In: MH Meyer (ed.) Care Work: Gender, Labor and the Welfare State. Routledge: New York, 232-248.

Kommunal (2014) Är det här okej? En rapport om villkoren för visstids- och timanställda. Stockholm: Kommunal.

Kröger T, Yeandle S (eds) (2013) Combining Paid Work and Family Care: Policies and Experiences in Comparative Perspective. Bristol: Policy Press.

Lloyd C and Payne J (2013) Changing job roles in the Norwegian and UK fitness industry: in search of national institutional effects. Work, Employment \& Society 27(1), 3-20

Mears J (2006), The World of Care Work: Report to the Benevolent Society. Sydney.

Morrison S (2015) Budget 2015: Supporting great choice for older Australians. Press release by Minister of Social Services, 12 May. Canberra: Parliament House.

NBHW (2013) Tillståndet och utvecklingen inom hälso- och sjukvård och socialtjänst. Lägesrapport 2013. Stockholm: Socialstyrelsen.

O’Reilly J (2006) Framing comparisons: gendering perspectives on cross-national comparative research on work and welfare. Work, Employment \& Society 20(4), 731-750.

OECD (2011) Help Wanted? Providing and Paying for Long-Term Care. Paris: OECD.

OECD (2013), OECD Family Database, Paris: OECD. www.oecd.org/social/family/database.

Productivity Commission (2013) An Ageing Australia: Preparing for the Future, Commission Research Paper. Canberra: Productivity Commission.

Ranci C and Pavolini E (2013) Reforms in Long-Term Care Policies in Europe: Investigating Institutional Change and Social Impacts. New York: Springer. 
Rostgaard T, Timonen V and Glendinning C (2012) Guest editorial: reforming home care in ageing societies. Health and Social Care in the Community 20(3), 225-227.

Rubery J and Urwin P (2011) Bringing the employer back in: why social care needs a standard employment relationship. Human Resource Management Journal 21(2), 122 137.

SALAR (Swedish Association of Local Authorities and Regions) (2014) Välfärdstjänsternas utveckling 1980-2014: ökande resurser och växande behov. Stockholm: SKL.

Schröder M (2013) Integrating Varieties of Capitalism and Welfare State Research. Basingstoke: Palgrave Macmillan.

Statistics Sweden (2013) Genomsnittlig grund- och månadslön samt kvinnors lön i procent av mäns lön efter region, sektor, yrke (SSYK) och kön. År 2005-2013. Stockholm: Statistics Sweden.

Stone D (2000) Caring by the book. In: M.H. Meyer (ed.) Care Work: Gender, Labor and the Welfare State. New York: Routledge, 89-111.

Stranz A (2013) Omsorgsarbetets vardag och vilkor i Sverige och Danmark: Ett feministiskt kritiskt perspectiv. PhD Thesis, Stockholm, Stockholm University.

Szebehely M, Trydegård G-B (2012) Home care for older people in Sweden: a universal model in transition. Health and Social Care in the Community 20(3), 300-309.

Trydegård G-B (2012) Care work in changing welfare states: Nordic care workers' experiences. European Journal of Ageing 9(2), 119-129.

Vabø M (2006) Caring for people or caring for quasi-consumers? European Societies 8(3): 403-422.

Vabø M, Szebehely M (2012) A caring state for all older people? In A Anttonen, L Häikiö and K Stefánsson eds Welfare State, Universalism and Diversity. Cheltenham: Edward Elgar.

Wærness K (1984) The rationality of caring. Economic and Industrial Democracy 5(2), 185211. 
Table 1: Demography, care resources, family care and women's work in Australia and Sweden

\section{Australia Sweden}

A. Older people in the population

$65+$ years

$80+$ years

B. Public expenditure on eldercare, \% GDP

0.8

C. FTE long-term care workers per 100 persons $80+$ years in the population

D. Proportion of all women of working age employed 30 hours per week or more

E. Proportion of family carers who give 20+ hours of care per week

Sources: A. OECD (2011: Figure 2.2); B. Productivity Commission (2013:148) and Huber et al. (2009:99); C. OECD (2011: Figure 1.6); D. OECD Family Database (2013, calculated from Table LMF 1.6 and Chart LMF 1.6.A); E. OECD (2011: Figure 3.3). 
Table 2: Workforce and employment characteristics, Australia, 2010; Sweden, 2005, per cent

\begin{tabular}{|c|c|c|}
\hline & $\begin{array}{c}\text { Australia } \\
(\mathrm{n}=318)\end{array}$ & $\begin{array}{l}\text { Sweden } \\
(n=166)\end{array}$ \\
\hline \multicolumn{3}{|l|}{ Gender (\%): } \\
\hline Female & 89.3 & 96.2 \\
\hline \multicolumn{3}{|l|}{ Age (\%): } \\
\hline-40 & 17.3 & 38.6 \\
\hline $41-50$ & 32.7 & 33.1 \\
\hline $51+$ & 50.0 & 28.3 \\
\hline \multicolumn{3}{|l|}{ Time working in care of older or disabled people (\%): } \\
\hline Less than 1 year & 6.9 & 1.2 \\
\hline $1-5$ years & 44.0 & 15.1 \\
\hline $6-9$ years & 23.0 & 18.7 \\
\hline $10-19$ years & 16.7 & 42.2 \\
\hline 20 or more years & 9.4 & 22.9 \\
\hline \multicolumn{3}{|l|}{ Working hours per week $(\%)$ : } \\
\hline 35 or more & 15.1 & 38.6 \\
\hline 30-34.9 & 22.3 & 31.9 \\
\hline 20-29.9 & 39.0 & 26.5 \\
\hline Less than 20 & 23.6 & 3.0 \\
\hline Want to work more hours $(\%)$ : & 32.1 & 17.5 \\
\hline Temporary employment (\%): & 25.1 & 12.1 \\
\hline
\end{tabular}


Table 3: Working hours, shifts and work-life balance, Australia, 2010; Sweden, 2005, per cent

\begin{tabular}{|c|c|c|}
\hline & $\begin{array}{c}\text { Australia } \\
\mathrm{n}=318\end{array}$ & $\begin{array}{c}\text { Sweden } \\
\mathrm{n}=166\end{array}$ \\
\hline \multicolumn{3}{|l|}{ Panel A. Shifts worked } \\
\hline Weekdays, day & 97.5 & $79.5^{* * * *}$ \\
\hline Weekends & 35.5 & $68.7^{* * *}$ \\
\hline Weekdays, evenings & 24.8 & $80.1^{* * *}$ \\
\hline Nights & 7.9 & $13.9^{* *}$ \\
\hline \multicolumn{3}{|l|}{ Panel B. Combinations of shifts (days, weekdays, evenings, nights) } \\
\hline One shift only & 62.9 & 16.9 \\
\hline Two shifts & 15.4 & 29.5 \\
\hline Three shifts & 14.4 & 47.6 \\
\hline Four shifts & 7.3 & 6.0 \\
\hline \multicolumn{3}{|l|}{ Panel C. How do working hours fit in with family or social commitments outside work? } \\
\hline $\begin{array}{ll}2 & \text { Very well }\end{array}$ & 52.2 & 16.2 \\
\hline Fairly well & 42.4 & 57.2 \\
\hline Not very well & 4.4 & 22.2 \\
\hline Not at all well & 0.9 & 4.4 \\
\hline
\end{tabular}




\begin{tabular}{|c|c|c|}
\hline & $\begin{array}{r}\text { Australia } \\
\mathrm{n}=318\end{array}$ & $\begin{array}{r}\text { Sweden } \\
\mathrm{n}=166\end{array}$ \\
\hline \multicolumn{3}{|l|}{ Do the following tasks at least daily: ${ }^{I}$} \\
\hline Assist with personal hygiene & 72.0 & $89.2^{* * *}$ \\
\hline Lift or assist in moving a person & 34.3 & $77.7^{* * *}$ \\
\hline Clean a client's home & 67.0 & $40.4^{* * *}$ \\
\hline Prepare a meal & 34.0 & $35.5^{\mathrm{NS}}$ \\
\hline Shop for groceries & 19.2 & $17.5^{\mathrm{NS}}$ \\
\hline Have a cup of coffee or tea with a client & 31.8 & $18.1^{* *}$ \\
\hline Carry out administrative tasks & 26.8 & $45.7^{* * *}$ \\
\hline \multicolumn{3}{|l|}{ Did the following task during last month working: ${ }^{2}$} \\
\hline Handed out medicine from a dispenser & 50.3 & $86.7^{* * *}$ \\
\hline Gave an injection & 1.6 & $36.7^{* * *}$ \\
\hline $\begin{array}{r}\text { Got in touch with the health care system or other supplier of care (outside the } \\
\text { workplace) }\end{array}$ & 20.8 & $69.3^{* * *}$ \\
\hline Carried out mobility or speech training/rehabilitation work & 11.6 & $56.6^{* * *}$ \\
\hline Participated in recreational activity with client(s) & 40.3 & $14.5^{* * *}$ \\
\hline
\end{tabular}

1 'Several times a day' or 'Once a day'. Other response alternatives: 'At least once a week'; 'At least once a month'; 'More rarely or never'.

${ }^{2}$ Response alternatives: Yes; No.

${ }^{*} p<0.05 ;{ }^{* *} p<0.01 ;{ }^{* * *} p<0.001$. 
Table 5: Workload and impact, job autonomy and support, and capacity to care, Australia, 2010; Sweden, 2005

Panel A per cent; Panel B Multiple logistic regression controlling for age, sex, length of time working in care of older and disabled people, hours of work and tasks provided (all 12 tasks in Table 4)

\begin{tabular}{|c|c|c|c|}
\hline & & el A & $\begin{array}{c}\text { Panel } \boldsymbol{B} \\
\text { Multiple logistic regression (Adjusted } \\
\text { odds ratios; reference category } \\
\text { Australia) }\end{array}$ \\
\hline & $\begin{array}{l}\text { Australia } \\
\mathrm{n}=318\end{array}$ & $\begin{array}{l}\text { Sweden } \\
n=166\end{array}$ & $\mathrm{n}=484$ \\
\hline $\begin{array}{l}\text { "I often get a lot out of working with my } \\
\text { clients" }\end{array}$ & 90.3 & $93.4^{\mathrm{NS}}$ & $2.30^{\mathrm{NS}}$ \\
\hline Feel physically tired after a working day ${ }^{2}$ & 48.4 & $62.7^{* *}$ & $1.47^{\mathrm{NS}}$ \\
\hline Feel mentally exhausted after a working day ${ }^{2}$ & 28.0 & $44.0^{* * *}$ & $1.38^{\mathrm{NS}}$ \\
\hline Have too much to do in the job ${ }^{3}$ & 6.0 & $32.5^{* * *}$ & $4.06^{* *}$ \\
\hline $\begin{array}{l}\text { Workplace is short-staffed due to illness, } \\
\text { vacation or unfilled vacancy }{ }^{4}\end{array}$ & 21.7 & $49.4^{* * *}$ & $2.46^{*}$ \\
\hline $\begin{array}{l}\text { Feel inadequate because clients are not } \\
\text { receiving the care they should }\end{array}$ & 5.7 & $22.3^{* * *}$ & $4.92^{* *}$ \\
\hline Get support from closest supervisor ${ }^{3}$ & 66.4 & $41.6^{* * *}$ & $0.60^{\mathrm{NS}}$ \\
\hline Can affect the planning of each day's work ${ }^{3}$ & 22.0 & $33.7^{* *}$ & $1.29^{\mathrm{NS}}$ \\
\hline $\begin{array}{l}\text { "It feels like management doesn't trust the } \\
\text { staff; there's too much monitoring and } \\
\text { control"l }\end{array}$ & 20.1 & $37.3^{* * *}$ & $1.71^{\mathrm{NS}}$ \\
\hline $\begin{array}{l}\text { Working conditions got worse in recent } \\
\text { years } 5\end{array}$ & 12.3 & $39.8^{* * *}$ & $2.28^{*}$ \\
\hline $\begin{array}{l}\text { Possibilities to meet clients' needs got worse } \\
\text { in recent years }{ }^{5}\end{array}$ & 12.9 & $47.6^{* * *}$ & $3.77^{* * *}$ \\
\hline
\end{tabular}

\footnotetext{
1 'Strongly agree' or 'Somewhat agree'. Other response alternatives: 'Somewhat disagree'; 'Strongly disagree'.

2 'Almost always' or 'Often'. 'Sometimes'; 'Rarely'; 'Never'.

3 'All or most of the time'. Other response alternatives: 'Sometimes'; 'Rarely'; 'Never'.

4 'More or less every day' or 'At least once a week'. Other response alternatives: 'At least once a month'; 'Less often'; 'Never'.

${ }^{5}$ Response alternatives: 'Mainly improved'; 'No difference'; 'Mainly got worse'.

$* \mathrm{p}<0.05 ; * * \mathrm{p}<0.01 ; * * * \mathrm{p}<0.001$
} 
Figure 1: Coverage of residential and home care services for people 65 years and older, Australia (2003-2012) and Sweden (1980-2012)

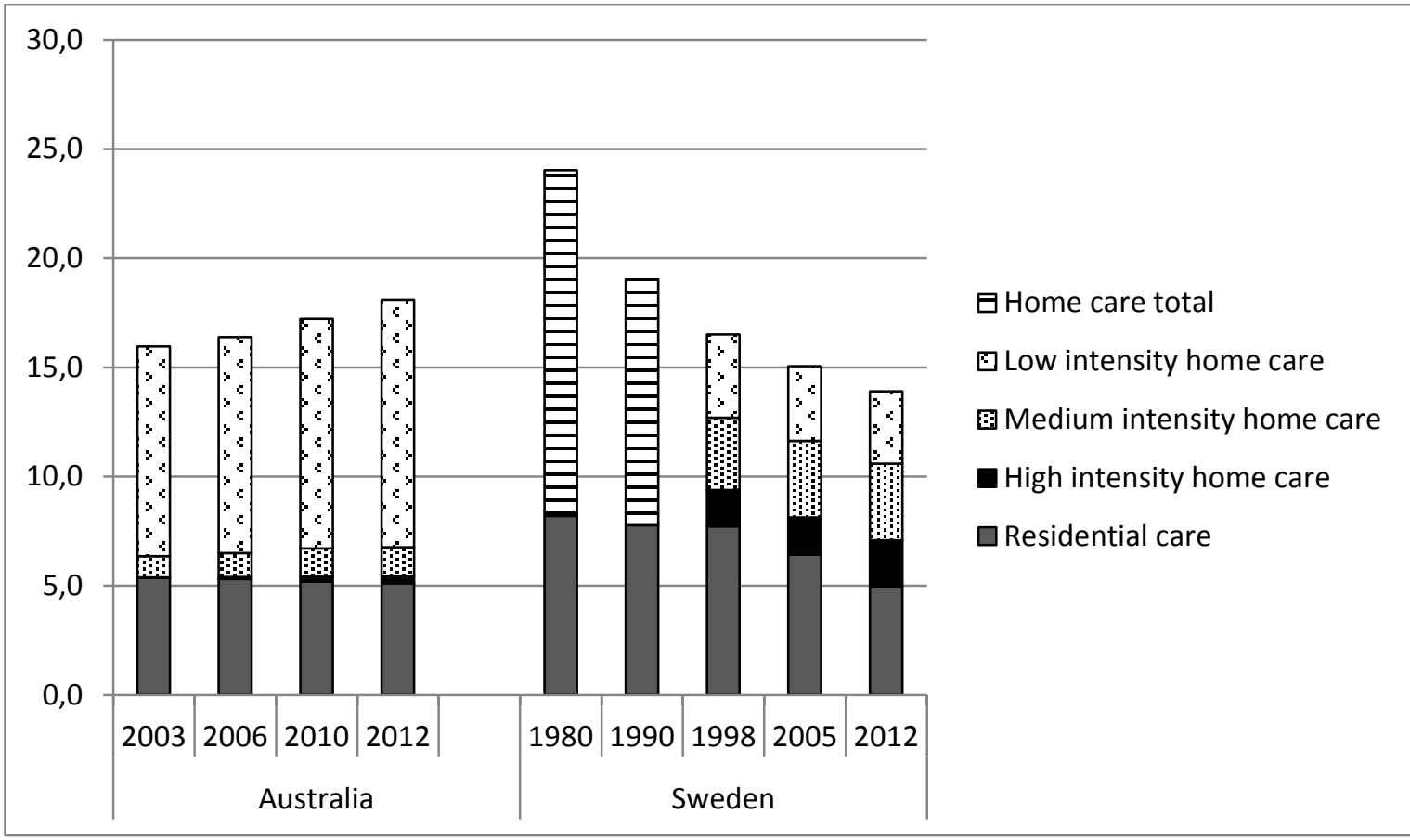

Sources: published and unpublished official statistics from each country; see Supplementary file for full information. 